\title{
Luasnya Perlindungan Paten
}

\author{
Peter Mahmud Marzuki
}

\begin{abstract}
Abstrak
The Scope of patent protection has been determined by the interpretation on the protection of claim. The study shows that if the protection concerns with the main invention which is described in the claim, the protection will be so broad that it prevents other people to modify and develop technology; on the contrany, if the protection concerns with the wording for patented counterfeiting which suffers injured for patent holder.
\end{abstract}

\section{Pendahuluan}

Luasnya perlindungan paten merupakan sesuatu yang potensial menyebabkan terjadinya konflik antara negara maju dengan negara yang sedang berkembang. Hal itu luasnya perlindungan paten berkenaan dengan adanya alih teknologi dari negara ke negaranegara yang sedang berkembang. Tidak dapat disangkal bahwa paten yang didaftarkan di negara-negara sedang berkembang sebagian besar dimiliki oleh perusahaan-perusahaan transnasional yang perusahaan induknya berada di negara-negara maju dan biasanya patennya atas nama perusahaan induknya atau dimiliki oleh perusahaan-perusahàan yang berkedudukan di negara-negara maju. Apabila perlindungan diberikan terlalu luas, akibatnya tidak terjadi alih teknologi sebab modifikasi yang paling besar pun dianggap pelanggaran paten. Sebaliknya, apabila perlindungan terlalu sempit, pemegang paten akan dirugikan karena adanya modifikasi yang tidak substansial terhadap paten yang ada dianggap sebagai penemuan baru dan juga dilindungi.

Luasnya perlindungan paten terletak pada klaimnya. Oleh karena itulah klaim merupakan sesuatu yang esensial di dalam paten. Persoalan yang terjadi adalah penafsiran mengenai klaim tersebut, yaitu apakah substansi dari klaim atau kata-kata klaim yang dilindungi. Hal tersebut membawa penentuan mengenai luasnya perlindungan paten.

Untuk mendapatkan pemahaman mengenai luasnya perlindungan paten, maka dilakukan studi perbandingan Undang-undang paten di beberapa negara. Yang akan dibandingkan adalah Undang-Undang Paten Amerika Serikat tahun 1952, Pasal 30 ayat (2) 
iijksoctrooiwet Belanda tahun 1910 yang telah mengalami berbagai perubahan terakhir pada tahun 1987, section 125 ayat (1) jo section 14 ayat (5) Patent Act Inggris 1977 dan Pasal 14 Patengezet Jerman. Kecuali Amerika Serikat, perundang-undangan paten negara-negara Eropa tidak dapat dilepaskan dari Konvensi Strasbourg 27 November 1963 yaitu Konvensi Paten Eropa tahun 1975.

\section{Makna Luasnya Perlindungan Paten}

Penentuan mengenai luasnya perlindungan penemuan merupakan sesuatu yang penting dilihat dari dua segi, yaitu dari segi ekonomi dan dari segi alih teknologi. Dilihat dari segi ekonomi, luasnya perlindungan penemuan bersangkut paut dengan masalah persaingan. Bukanlah sesuatu yang tidak mungkin kalau terdapat lebih dari satu orang pemohon paten yang di suatu negara tertentu untuk penemuan-penemuan yang mirip satu terhadap yang lain. Apabila hal ini terjadi secara hukum dapatlah dipastikan bahwa pemohon pertamalah yang akan diberikan paten oleh negara itu. Dengan diberikannya paten kepada pemohon pertama, telah tertutup kemungkinan bagi para pemilik penemuan yang permohonan patennya ditolak oleh Kantor Paten negara tersebut untuk mendayagunakan penemuannya sendiri mereka harus membayar biaya ekstra. Sedangkan sebagaimana yang telah diketengahkan bahwa untuk mendapatkan penemuan diperlukan adanya kegiatan Research and Development (R\&D) yang menelan biaya sangat besar.
Dalam hal itu tampaknya prinsip ekonomi dikalahkan oleh sekedar formalitas. Namun demikian demi kepastian hukum prinsip paten semacam itu perlu dipertahankan. Betapa pun ungkapan lex dura sed tamen scripta yang terjemahannya kira-kira "undang-undang memang keras tapi memang begitu bunyinya" masih perlu dipertahankan. Dengan berpegang kepada kepastian hukum, pemilik penemuan yang ditolak permohonan patennya karena penemuannya mirip dengan penemuan yang telah diberi paten harus bersedia untuk "merelakan" penemuannya itu tidak diberi paten. Akan tetapi tidaklah adil jika pemilik penemuan yang ditolak permohonan patennya ini melakukan modifikasi terhadap penemuan tersebut dianggap telah melakukan pelanggaran hukum karena melakukan peniruan terhadap penemuan yang telah diberi paten. Di sinilah perlu diperhatikan unsur keadilan sebagai salah satu tujuan hukum. Menurut IImu Hukum, adalah merupakan sesuatu yang adil apabila kepentingan setiap subjek hukum dilindungi sebagaimana mestinya.

Di samping kepastian hukum dan keadilan, perlu kiranya diperhatikan juga unsur kemanfaatan menyangkut kesejahteraan orang banyak. Jeremy Bentham yang pertama kali mengemukakan doktrin utility di dalam hukum. Menurut doktrin ini hukum harus memberikan sebanyak mungkin kebahagiaan kepada sebagian besar orang. ${ }^{1}$ Pernyataan Bentham itu kiranya dapat dipahami. Hukum itu sendiri diadakan untuk mengatur transaksi

'P. Van Dijk, et al. 1985. Van Apeldoorn's Inleiding tot de Studie van het Nederlandse Recht. W.E.J. Tjeen-Willink. Zwolle. HIm. 16. 
kehidupan bermasyarakat agar kehidupan bermasyarakat tidak runtuh. Dalam hal inilah perlu pengaturan yang seimbang antara kepentingan individu dan kepentingan masyarakat. Apabila prinsip ini diterapkan ke dalam perundang-undangan paten, perlindungan paten di samping untuk melindungi kepentingan individu juga harus bermanfaat bagi masyarakat luas.

Salah satu manfaat pertindungan paten bagi masyarakat adalah penyebarluasan teknologi termasuk di dalamnya alih teknologi. Dengan diberikannya paten kepada pemilik penemuan tertentu diharapkan terjadi pengungkapan teknologi melalui modifikasi terhadap penemuan sehingga dimungkinkan terjadinya alih teknologi. Apabila perlindungan terhadap penemuan mempunyai jangkauan yang luas, boleh dikatakan setiap modifikasi terhadap penemuan akan dipandang sebagai pelanggaran terhadap perundang-undangan paten. Akibatnya, tidak mungkin terjadi modifikasi terhadap penemuan itu dan dengan demikian juga tidak terjadi alih teknologi. Oleh karena, itu perlu ditentukan luasnya perlindungan penemuan.

\section{Luasnya Perlindungan Paten}

Undang-Undang Paten negara-negara Eropa tidak dapat dilepas dari konvensi Strasbourg. Konvensi Strasbourg disiapkan oleh Comite d'expeets en matiere de brevets dalam rangka kerjasama Dewan Eropa. Konvensi ini mulai berlaku sejak 1 Agustus 1980. Menurut artikel 8 ayat (3) Konvensi itu
"The extent of protection conferred by the patents shall be determined by the terms of the claims". Ketentuan 'itu sejalan dengan Pasal 69 ayat (1) Konvensi Paten Eropa yang berbunyi: The extent of the protection confered by a European or a European paten application shall be determined by the term of claims. Nevertheless, the description and drawings shall be used to interpret the claims.

Meskipun negara-negara Eropa menandatangani kedua konvensi itu telah menyesuaikan perundang-undangan nasional mereka terhadap kedua konvensi tersebut, ternyata masih terdapat perbedaan penafsiran tentang luasnya perlindungan paten. Di Belanda ketentuan Pasal 8 ayat (3) Konvensi Strasbourg dan Pasal 69 ayat (1) Konvensi Paten Eropa yang tertuang di dalam Pasal 30 ayat (2) Rijksoctrooiwet 1910. Ketentuan itu merupakan sesuatu yang baru dalam perundangundangan paten Belanda. Sampai tahun 1977 perundang-undangan paten Belanda tidak mengenal ketentuan mengenai luasnya perlindungan paten. ${ }^{2}$ Ketentuan Pasal 30 ayat (2) Rijksoctrooiwet tersebut baru diadakan pada tahun 1978. Memang, sejak diundangkan pada tahun 1910, Undang-Undang Paten Belanda ini telah mengalami berbagai perubahan dan perubahan terakhir terjadi pada tahun 1987 melalui Undang-Undang 29 Mei 1987 yaitu mengenai penyesuaian Rijksoctrooiwet terhadap Patent Cooperation Treaty. Sebelumnya, berdasarkan Undang-Undang 13 Desember 1978, Rijksoctrooiwet disesuaikan dengan Konvensi Paten Eropa. Sedangkan persetujuan terhadap Konvensi Strasbourg

${ }^{2}$ A.P Piroen. 1988. Bescherming Omvang van Octrooien in Nederland, Duitsland, en Engeland. Kluwer. Deventer. HIm. 112-113 
dilakukan berdasarkan Undang-Undang ini bukan merupakan perubahan terhadap Rijks octrooiwet yang telah diubah berdasarkan Undang-Undang 13 Desember 1978. Tidak dimaksudkannya undang-undang mengenai Persetujuan terhadap Konvensi Strasbourg sebagai perubahan terhadap Rijks octrooiwet dapat dipahami karena mengenai luasnya perlindungan penemuan, tidak ada perbedaan antara Pasal 8 ayat (3) konvensi Strasbourg dan Pasal 69 ayat (1) Konvensi Paten Eropa. Namun demikian, perlu diketengahkan di sini bahwa menurut Undang-Undang Dasar Belanda, Konvensi yang diikuti oleh Belanda mempunyai kedudukan yang lebih tinggi dari hukum nasional Belanda, yang harus disisihkan adalah hukum nasionalnya. Di samping itu, konvensi tersebut dapat langsung menjadi sumber nasional hukum Belanda.

Sejalan dengan Pasal 8 ayat (3) Konvensi Strasbourg dan Pasal 69 ayat (1) Konvensi Paten Eropa, Pasal 30 ayat (2) Rijksocstrooiwet 1910 menetapkan Het uitsluitend recht wordt bepaald door inhoud van de conclusies van het octrooischrift, woorbij de beschrijving en de tekeningen dienen tot uitleg van die conclusies. Berdasarkan ketentuan tersebut, yang dilindungi oleh Undang-Undang Paten Belanda adalah isi klaim, buka perumusan secara harfiah klaim yang disertakan dalam permohonan paten suatu penemuan. Di dalam Penjelasan Umum Undang-Undang 6 November 1986, disebutkan antara lain:

"...Ten aanzien van de uitleg van de beschermingsomvang zijn er twee tegenstelde belangen: die van de octrooihouder en die van de gemeenshap die met het uitsluitend recht wordt geconfronteerd. De octrooihauder heeft er belang bij de beschermingsomvang van zijn ocstrooi zo ruim mogelijk uit leggen om ook toepassingen van de uitvinding die bij de ocstrooiverlening nog niet voorzien konden woorden voor anderen uit te sluiten. De gemenschap, in de eerste plaats de concurerende derden, zal in de oetoefening van een bedrijf zo min mogelijk door uitsluitende rechten wensen te worden gehinderd, en indien dit toch het geval is, op zo voorspelbaar mogelijk wijze. De rechsonde moet deze twee belangan in evenwicht hauden..."

Dari kalimat terakhir Penjelasan Umum Undang-Undang tentang Persetujuan Konvensi Strasbourg itu dapat ditangkap maksud pembuat undang-undang bahwa perlindungan terhadap penemuan janganlah terlalu luas tetapi juga jangan terlalu sempit. Jika terlalu luas yang dirugikan adalah masyarakat sedangkan kalau terlalu sempit membuka kesempatan untuk terjadinya peniruan sehingga merugikan adalah pemégang paten. Perlu diketengahkan di sini bahwa yang dimaksud dengan masyarakat dalam konteks ini adalah masyarakat pengusaha. Pembentuk undang-undang tidak bermaksud mengkaitkan luasnya perlindungan paten ini dengan masalah alih teknologi. Hal ini disebabkan setting masyarakat Belanda dengan pola perekonomian yang sudah maju dengan dijiwai oleh semangat kapitalisme. Oleh karena, itulah kepentingan masyarakat dalam undangundang ini bukan berarti kepentingan bersama, melainkan kepentingan dalam mempertahankan sistem kapitalisme. Salah satu upaya untuk mempertahankan sistem kapitalisme adalah mempertahankan persaingan. Apabila perlindungan terhadap penemuan 
ditafsirkan terlalu luas, hal itu akan mengganggu persaingan. Hal seperti itulah yang ingin dihindari baik oleh konvensi Strasbourg maupun oleh konvensi Paten Eropa.

Sikap Pengadilan Belanda tidak terikat pada Penjelasan Undang-Undang. Hakim diberikebebasan dalam menafsirkan ketentuanketentuan undang-undang. Sebelum Rijksoctrooiwet mengalami perubahan, yang dianggap sebagai landmark decision dalam kasus paten adalah Putusan Hoge Raad tanggal 20 Juni 1930 atas kasus Philips/Tasseron. ${ }^{3}$

Dalam kasus itu yang dianggap sebagai pokok klaim yang menjadi obyek sengketa adalah skakelar seri dari versterker-versteker thermionis, dengan ciri bahwa plat-platnya dihubungkan dengan sesuatu platbatterij oleh sesuatu tahanan yang besar dan kisi-kisinya dihubungkan dengan suatu titik dari potensial konstan oleh tahanan yang besar, sedangkan hubungan antara plat yang satu dan kisi dari vesteker berikutnya terbentuk oleh suatu kondensator.

Tertuduh Tasseron di dalam bisnisnya telah memasarkan versterker-versterker semacam itu tanpa plaatbatterij. Namun demikian Hogerechtshop (Pengadilan Banding) yang mengadili sengketa itu berpendirian bahwa yang dilindungi oleh undang-undang adalah het wezen der zaak de geoctrooieerde uitvinding bestaat. ${ }^{4}$ Berdasarkan pendirian itulah Tasseron dianggap telah melaksanakan essentiele kenmerk (ciri yang esensial) paten nomor $10155 .{ }^{5}$ Perbuatan tersebut dapat di- pandang sebagai pelanggaran hukum. Kiranya pendirian yang dianut oleh Hof ini sama dengan pendirian Hoge Raad (Mahkamah Agung Belanda).

Meskipun telah terjadi perubahan yang cukup berarti di dalam Rijksoctrooiwet 1910 mengenai luasnya perlindungan paten terhadap penemuan sebagaimana dituangkan di dalam Pasal 30 ayat (2) undang-undang itu, pendirian Pengadilan Belanda ternyata tidak mengalami perubahan. Beberapa Pengadilan Tinggi di beberapa tempat di Belanda telah berusaha untuk tidak lagi menafsirkan inhoud van conclusies sebagai het wezen der zaak de geoctrooieerde uitvinding bestaat. Salah satu di antaranya adalah putusan haagse hof pada 16 Februari 1983 atas kasus naadlos buis menggunakan lezing van het ganse ocstrooischrift sebagai landasan dalam menentukan luasnya perlindungan paten. Akan tetapi, hoge raad masih belum beranjak dari pendirian tahun 1930-an yang memandang het wezen der zaak de geoctrooierde bestaat sebagai batasan dalam menentukan luasnya penemuan.

Menurut Pieroen, pendirian pengadilan Belanda itu sudah sesuai dengan maksud yang dikandung baik oleh Konvensi Strasbourg maupun Konvensi Paten Eropa karena memberikan perlindungan yang seimbang baik terhadap pemegang paten maupun kepada pihak ketiga. ${ }^{6}$ Protokol Konvensi Paten Eropa memang menghendaki adanya perlindungan hukum yang seimbang antara pemegang paten dan masyarakat.

\footnotetext{
3/bid. HIm. 173.

$4 /$ bid. HIm. 174.

s/bid.

olbid.
} 
Sebagaimana di Belanda, di Jerman sebelum 1 Januari 1978 juga belum ada ketentuan luasnya perlindungan paten. Setelah diberlakukannya Undang-Undang Paten 1887, biasanya yang dilindungi adalah paten anspruch atau kata-kata dalam klaim. Akan tetapi lambat laun, luasnya perlindungan semakin besar. Sebelum Perang Dunia II, praktek pengadilan Jerman menerapkan Zweiteilungslehre. Dalam ajaran ini dibedakan ántara Gegentand der erfindung (objek penemuan) dạn allgemeinere Erfindungsgedanke (ide inventif secara umum). Perlindungan, menurut ajaran ini, diberikan sampai kepada ide inventif secara umum. ${ }^{7}$ Sedangkan uraian tertulis mengenai penemuan sedikit sekali diperhatikan. Oleh karena yang diberi perlindungan adalah ide atau gagasan dapat dikatakan bahwa menurut ajaran ini, pertindungan yang diberikan kepada penemuan sangat luas sehingga sulitlah ditentukan batas-batas perlindungan terșebut. Akibatnya tidak terdapat kepastian hukum kepada pihak ketiga.

- Sekitar tahun 1931-1932 timbul gagasan untuk memberikan syarat-syarat yang lebih ketat bagi tambahan luasnya perlindungan uraian tertutis mengenai penemuan yang.tertuang di dalam kata-kata klaim. ${ }^{8}$ Setelah perang dunia II timbul dreiteilungslehre sebagai ganti zweiteilungslehre. Menurut Dreiteilungslehre, yang disebut gegenstand der erfindung oleh Zweitengslehre, oleh Dreiteilungslehre dinamakan unmit telbare gegenstand der erfindung (objek penemuan langsung); sedangkan allgemeinere erfindung sgedanke dibedakan menjadi gegenstand der erfindung (tetapi istilah ini berbeda dengan yang digunakan oleh zweteilunglehre) dan allgemeine erfindungsgedanke. Arti penting Dreiteilungslehre terletak pada pemikirannya mengenai syarat-syarat perlindungan di luar penguraian klaim yang diberikan secara tertulis.

Yang dimaksud dengan gegenstand der erfindung oleh Dreiteilungslehre adalah pengetahuan teknis yang dapat dicapai oleh orang ahli biasa pada saat dipatenkan tanpa perlu memperhatikan secara khusus terhadap deskripsi, gambar-gambar, dan state of the art yang tercantum di dalam klaim. Gegenstand tersebut biasanya meliputi type-type perwujudan penemuan yang tidak tepat sama dengan kata-kata klaim, misalnya perwujudan yang ekuivalen dengan yang diuraikan dalam klaim, perwujudan penemuan yang belum selesai. Unmittelbare Gegenstand der erfindung merupakan apa yang diuraikan sesuai dengan kata-kata dalam klaim. Ini merupakan suatu perlindungan yang minimal yang harus diperhatikan oleh Pengadilan Paten. Sedangkan Algemeine Erfindungsgedanke dapat disebut sebagai generalisasi Gegenstand der Erfindung yaitu apabila seorang ahli biasa hanya dapat memperoleh pengetahuan pada hari pertama dipatenkan setelah memberikan perhatian secara khusus kepada klaim meskipun tanpa langkah inventif. Allgemeine Erfindungsgedanke dapat meliputi berbagai variasi perwujudan penemuan yang tidak dicakup oleh Gegenstand der Erfindung.

'Ilbid. HIm. 413.

8bid. HIm. 414. 
Ajaran inipun dinilai memberikan perlindungan yang sangat luas kepada pemegang paten. Akibatnya, kepastian hukum juga sangat rendah. Sejak 1 Januari 1978 terjadi perubahan yang sangat drastis, yaitu dengan berlakunya ketentuan perundang-undangan baru, Konvensi Strasbourg, dan Konvensi Paten Eropa. Ketentuan-ketentuan itu merupakan upaya untuk menyisihkan Dreiteilungslehre yang memberikan perlindungan begitu besar kepada penemuan. Dengan ketentuan-ketentuan baru itu, luas perlindungan paten dipersempit. Menurut ketentuan yang baru yang sekarang telah dituangkan ke dalam Pasal 14 Patengesetz 1981, luasnya perlindungan paten ditentukan oleh inhalt (isi materiil) klaim. Dengan berpegang pada ketentuan baru itu, mayoritas para ahli berpendapat bahwa perlindungan di luar kata-kata klaim hanya dapat diperluas untuk: (a) perwujudan penemuan yang ekuivalen, (b) perwujudan penemuan yang belum selesai, dan (c) perwujudanperwujudan penemuan yang berbeda dari klaim utama yang di dalamnya tidak terdapat ciri-ciri yang non-esensial. Dengan demikian perlindungan tersebut masih terlalu luas.

Apabila Jerman memberikan perlindungan yang luas kepada penemuan, meskipun sama-sama merujuk kepada Konvensi Strasbourg dan Konvensi Paten Eropa, Inggris memberikan perlindungan yang sempit bagi luasnya perlindungan penemuan. Sebelum Patents act 1977, perundangundangan paten Inggris, baik Patents, Design, and Trade Mark Act 1883 maupun Paten Act 1949 tidak mengatur luasnya perlindungan penemuan. Penentuan luasnya perlindungan penemuan dilakukan berdasarkan penafsiran hakim yang dituangkan melalui putusan peradilan. Hal ini sesuai dengan doktrin stare decisis yang dianut sistem hukum Inggris sebagai suatu negara penganut Common Law System. Namun demikian, section 5 ayat (5) Patents, Designs, and Trade Mark Act 1883 menetapkan bahwa penguraian klaim must particularly describe and ascertain in the nature of the invention, and in what manner it ir to be performed. Jiwa ketentuan ini masih dipertahankan di dalam Patents Act 1949 meskipun dirumuskan secara lain. Section 4 ayat (3) a dan c Patents Act 1949 berbunyi: "Every complete specification (a) shall particularly describe the invention and the method by which it is to be perfomed ... (b) shall end with a claim or defining the scope of the infention claimed".

Dengan adanya kewajiban untuk merumuskan klaim sebagaimana diinginkan oleh kedua Undang-undang itu, hakim berpegang kepada pengertian secara gramatikal seperti yang diuraikan di dalam klaim. Oleh karena itulah timbul kecenderungan untuk menuliskan klaim secara luas sehingga bisa dikatakan meliputi semua kemungkinan yang dapat dipikirkan. Kenyataan semacam inilah menyebabkan hakim Laurence dalam kasus British harfor $v$ Jackson menyatakan one of the cardinal rules in that of patentee must mark out the temitory intended to be covered by his monopoli in clear and unambiguous language 9 pernyataan itu ditegaskan oleh hakim Romer bahwa it is the duty of a patentee to describe his invention in unambiguous lenguage and to define with precision the limits of the monopoly that he claims. Selanjutnya di dalam kasus Emy

9bid. HIm. 577 
$\checkmark$ Lissen, House of lords lebih jauh menjelaskan ${ }^{10}$ The function of a claim is to define clearly and with precision the monopoly climed, so that others may know the exact boundaries of the area within which they will be trespassers. Their primary object is to limit not to extend the monopoly ...(Kursif dari saya, PMM).

Baik pernyataan house of lords maupun pertimbangan-pertimbangan yang diberikan oleh hakim-hakim dalam kasus-kasus yang telah disebutkan, dapat dikatakan bahwa tujuan pembatasan monopoli adalah untuk kepastian hukum. Adanya kepastian hukum tersebut diperlukan agar setiap orang yang melakukan modifikasi terhadap klaim tidak terjatuh ke dalam peniruan yang merupakan perbuatan melanggar hukum.

. Pada tahun 1977 diundangkan Patents Act menggantikan Patents Act 1949, diundangkannya Patents Act 1977 itu dalam rangka menyelaraskan dengan konvensi Strasbourg dan Konvensi Paten Eropa. Di dalam section 125 ayat (1) Patents Act ini diatur mengenai luasnya perlindungan penemuan yang mengacu kepada Pasal 8 ayat (3) Konvensi Strasbourg dan Pasal 69 ayat (1) Konvensi Paten Eropa. Akan tetapi di dalam pelaksanaannya hakim tetap memiliki kebebasan yang besar dalam - menentukan batas luasnya perlindungan penemuan.

Pada tahun 1980 terdapat suatu putusan terhadap Catnic v Hill and Smith. Putusan ini boleh dikatakan sebagai suatu Landmark decision setelah diundangkannya Patents Act 1977. Kasus itu mengenai balok penopang yang dibuat dari plat dan dimasukkan ke tembok-tembok bangunan di atas pintu dan jendela. Klaim utama pemegang paten antara lain berisi ciri-ciri: (a) First rigid support member extending downwardly and forwradly frong or nier the front edge; (b) second rigid support member extending vartically from or near the rear edge. Menurut uraian dalam klaim, member yang terdapat pada (a) yaitu yang berada di depan, mempunyai kemiringan 12-13 derajat. Ini berarti bahwa member tersebut tidak dapat dikatakan vertikal. Sedangkan member (b) yaitu yang di belakang jelas-jelas yertikal.

Kemudian ada orang lain yang membuat balok penopang dari baja dengan bagian belakang tidak tepat berdiri vertikal melainkan sedikit miring. Terhadap kasus ini Hakim Tinggi Whitford dalam pertimbangannya menyatakan bahwa vertikal bukan merupakan ciri esensial sehingga antara balok yang telah dipatenkan dan balok tergugat tidak terdapat perbedaan. Sedangkan Court of Appeal memandang bahwa vertikal merupakan ciri yang esensial karena apa yang tertulis di dalam klaim, itulah yang dikehendaki oleh pemohon. Oleh karena itulah Court of Appeal memandang bahwa antara balok yang telah dipatenkan dan balok tergugat terdapat perbedaan, sehingga dalam hal ini tidak terjadi pelanggaran hukum. Mengenai masalah ini Hause of Lords memandang bahwa yang menjadi ukuran adalah purposive construction dari pemohon. Sejak saat itulah pengadilan-pengadilan Inggris banyak yang merujuk kepada ajaran purposive construction ini. Dengan berpegang pada ajaran ini, luasnya perlindungan penemuan lebih besar dari sekedar berdasarkan kata-kata

${ }^{10} /$ bid. Hlm. 578. 
klaim. Namun demikian tidak seperti di Jerman yang memberikan tempat begitu besar kepada luasnya perlindungan penemuan, karena di Inggris dalam praktek dianut bahwa ${ }^{i t}$ Strict compliance with a particular descriptive word or phrase appearing in a claim was intended by the patentee to be essential requirement of the invention so that any variant would fall outside the monopoly claimed, even if it could have no material effect upon the invention worked.

\section{Doktrin File Wrapper Estoppel dan Doktrin Equivalent}

-Luasnya perlindungan penemuan di inggris masih lebih besar dibandingkan dengan yang diberikan oleh Hukum Amerika Serikat. Dalam Undang-Undang Paten Amerika Serikat tidak diatur luasnya perlindungan penemuan sebagaimana yang dapat diketemukan dalam perundang-undangan paten negara-negara Eropa dan Konvensi Strasbourg maupun Konvensi Paten Eropa. Di Amerika Serikat dikembangkan doktrin file wrapper estoppel dan doktrin equivalent. Dalam menentukan ada atau tidaknya pelanggaran terhadap suatu penemuan yanig dipatenkan yang pertama kali harus diperhatikan adalah kata-kata klaim. ${ }^{12}$ Namun pengadilan juga telah mengakui bahwa untuk mengizinkan peniruan yang tidak mengkopi setiáp tulisan secara mendetail terhadap penemuan yang telah dipatenkan sama halnya dengan menjadikan perlindungan sesuàtu yang sia-sia dan tidak berguna.
Pembatasan semacam itu akan memberikan kesempatan kepada peniru yang tidak bertanggung jawab untuk melakukan perubahanperubahan dan substitusi yang tidak penting dan tidak substansial meskipun sebenarnya taripa menambah sesuatu dengan cara meniru sedemikian rupa paten itu di luar klaim sehingga berada di luar jangkauan hukum. Seseorang yang membajak suatu penemuan sebenarnya sama halnya dengan seseorang yang membajak buku atau drama yang dilindungi oleh hak cipta dengan cara melakukan perubahan kecil sehingga dapat berlindung di balik hukum. Apabila hanya kata-kata. yang harus diperhatikan, pengadilan berpendapat bahwa hal itu akan menempatkan bentuk lebih tinggi dari pada substansi. Hal itu sudah barang tentu akan merampas keuntungan yang sedianya diperoleh pemilik penemuan. Hal ini jelas tidak sesuai dengan penemuan tujuan utama sistem paten yaitu pengungkapan penemuan (prinsip disclosure).

Untuk melindungi pemilik penemuan yang dipatenkan dikembangkan doktrin equivalent. Menurut doktrin apabila dua alat mempunyai fungsi yang' sama dengan cara bekeija yang secara substansial sama, dan untuk memperoleh akibat yang secara substansial sama kedua alat itu dianggap sama, meskipun kedua alat itu berbeda baik nama, bentuk, maupun wujudnya. Secara umum doktrin ini memang menguntungkan pemilik penemuan. Namiun dari sisi lain doktrin dapat juga digunakan untuk menyerang pemilik penemuan. Hal ini terjadi

"lbid. Hllm.696-700.

${ }^{12}$ Paul Goldstein. 1981. Cases and Materials on the Law of Intelectual Property. New York: Mineola. HIm. 647-651. 
apabila alat yang dipatenkan itu diubah sedemikian rupa sehingga cará bekerjanya secara substansial berbeda jauh dari barang yang dipaténkan tetapi berfungsi sama dengan yang telah dipatenkan dan masih tercảkup dalam kata-kata klaim. Jika hal itu "dilakukan oleh pemilik paten, doktrin equivalent akan digunakan untuk membatasi klaim itu dan dalam hal terjadi sengketa bukan tidak mungkin doktrin itu akan menyulitkan pemegang paten.

Dalam perkembangannya, doktrin equivalent itu berkaitan dengan doktrin file wrapper estoppel. Menurut doktrin yang terakhir ini, guna memperoleh paten, pemilik penemuan membatasi klaimnya. Apabila doktrin ini telah digunakan dalam mempertahankan patennya dari peniruan, pemegang paten dapat menggunakan doktrin equivalent. Penggunaan doktrin tersebut pada saat ini hanya untuk klaim-klaim yang ambigious dan sebagai alat interpretasi.

Menurut Mahkamah Agung Amerika Serikat, "The purpose of the doctrine of equivalents is to prevent others from avoiding the patent by merely making unimportant and insubstantial changes and substitutions in the patent". ${ }^{13}$ Di dalam kasus Alpex Computer Corporation $v$ Nintendo Company Ltd and Nintendo America; Inc., Alpex sebagai pemegang paten No. 4,026, 555 menggugat Nintendo bahwa Nintendo telah melakukan pelanggaran terhadap paten tersebut: Baik penggugat maupun tergugat adalah produsen video games. Industri video games telah mulai sejak awal 1970-an. Pada saat ini berkembang dua macam video games dan home video games. Yang pertama dapat dijumpai di tempat-tempat permainan sedangkan yang kedua biasanya dijumpai di rumahtangga. Pada tahun 1974, Alpex menemukan suatu sistem yang memungkinkan home video games memainkan berbagai permainan termasuk permainanpermainan dengan gambar yang berotasi. Temuan itu kemudian mendapat paten pada tahun 1977. Temuan yang telah dipatenkan itu kemudian dikomersialkan dalam sistem oleh Attari, Mattel, dan Coleco.

Tahun 1980 awal Nintendo juga masuk ke pasaran home video games dengan Nintendo Entertainment System (NES). Setelah NES menjadi feature pada Consumer Electronic Show 1985, Alpex memberi tahu Nintendo bahwa Nintendo telah melanggar patennya. Oleh karena itulah pada bulan Februari 1986, Alpex menggugat Nintendo. Kedua belah pihak sebenarnya berkali-kali mengusahakan penyelesaian di luar pengadilan. Oleh karena itulah para pihak kemudian maju ke pengadilan. Pada pengadilan tingkat pertama Alpex dimenangkan. Pertimbangan pengadilan tersebut adalah antara alat yang telah dipatenkan dan alat yang dianggap sebagai tiruan dilihat dari segi fungsi, cara dan hasilnya tidak mempunyai perbedaan yang substansial. Namun pengadilan tingkat pertama tersebut tidak membuktikan bahwa kedua alat tersebut benar-benar bekerja

${ }^{13}$ Alpex Computer Corporation v Nintendo Company Ltd. And Nintendo of Americca, Inc. United States Court of Appeals for the federal Circuit. November 6, 1996. 
dengan cara yang secara substansial adalah sama. Oleh karena itulah kemudian pengadilan tingkat banding menafsirkan doktrin equivalent bukan semata-mata bahwa kedua alat itu equivalence of the functional result, melainkan harus dapat dibuktikan bahwa keduanya mempunyai perbedaan yang tidak substansial dalam cara kerjanya.

Kiranya doktrin ini juga dipergunakan dalam sistem paten Jepang. ${ }^{14} \mathrm{Di}$ dalam Undang-Undang Paten Jepang yaitu UndangUndang Nomor 21/1959 dikenal aturan mengenai luasnya perlindungan penemuan. Ketentuan ini terdapat pada Pasal 70 undangundang tersebut. Di dalam kasus Badische Anilin and Soda Fabrik A.G. v Sekiskui Kagaku Kogyo KK and Sekisui Sponge, District Court Osaka menafsirkan luasnya perlindungan penemuan menurut Pasal 70 sebagai berikut:15

"Essentially, the statement of the scope of claim for patent is nothing more than a simple and clear indication of the essential features of the invention (matters such as are indispensable for the construction of the invention) as written into the section of the detailed statement which calls for " $A$ in some cases to abstract and in others too brief, with the resultthat difficulty arising in fixing the tehnical scope of invention. Thus, in establishing the technical scope of the patented the patent invention, the statement of the scope claimed for the patent should, of course, be the basis. This does not mean, however, that supplementaryassessment based on other resource materials not permitted. It is permissible to reach assessment by taking account, in certain circumstances .... It would accordingly, be proper and right to hold that this Article goes no further than to expressly state that in determining the technical scope of a patented invention, we should not take up as the substance of the invention anything not actually describe in it or anything departing from the entries under the scope claimed for the patent".

Di dalam kasus itu pengadilan tersebut menerapkan doktrin equivalent. Pengertian equivalent yang dikembangkan oleh pengadilan Jepang itu sama dengan yang dianut di Amerika Serikat. Sedangkan doktrin file wrapper estoppel, diterapkan dalam kasus Muranaka $\checkmark$ K. K. Daiwa Gomu Seisakusho. Oleh karena sistem hukum Jepang didasarkan atas tradisi Civil Law, prinsip iktikad baik yang terdapat dalam Kitab Undang-Undang Hukum Perdata Jepang digunakan dalam situasi pada saat doktrin file wrapper estoppel diterapkan.

Dari sistem-sistem yang telah dikemukakan tersebut yang dapat dikatakan seimbang dalam memberikan perlindungan antara pemegang paten dan masyarakat adalah sistem Amerika Serikat dan tentu saja Jepang yang memang meniru sistem Amerika. Di dalam sistem Amerika Serikat tersebut, terbuka kesempatan bagi hakim untuk melakukan penafsiran secara teologis, yaitu sesuai

\footnotetext{
"Terio Doi. The Intellectual Property Law of Japan. Sijthoff \& Noordhoff. Alphen aan den Rijn. The
} Netherlands. 1980. Hilm. 35.

$15 /$ bid. 
dengan kepentingan yang dihadapi pada saat itu. Hal ini dimungkinkan karena luasnya perlindungan penemuan tidak diatur di dalam perundang-undangan. Oleh karena itu di dalam menentukan luasnya perlindungan penemuan tersebut diserahkan kepada kebijaksanaan hakim. Hal itu sesuai dengan sistem Common Law yang dianut oleh Amerika Serikat. Di dalam sistem Common Law hakim memang memiliki diskresi yang besar.

Yang menarik untuk diperhatikan adalah sistem Jepang. Jepang yang menganut tradisi Civil Law ternyata telah dengan tidak segansegan "mengimpor" doktrin-doktrin yang berkembang di dalam sistem Common Law. Doktrin-doktrin yang berkembang di dalam sistem Common Law itu dengan berhasil dikemas di dalam prinsip yang lazim digunakan di dalam sistem Civil Law. Sikap dan keterampilan semacam itu sangat dibutuhkan dalam mengembangkan hukum yang sesuai dengan kebutuhan masyarakat yang oleh Seiznick dan Nonnet disebut sebagai Responsive Law. ${ }^{16}$

\section{Luasnya Perlindungan Paten Menurut Hukum Indonesia}

Di dalam Pasal 30 ayat (2) huruf (h) Undang-Undang No. 6 Tahun 1989 yang telah diubah dengan Undang-Undang No. 13 Tahun 1997 disebutkan bahwa klaim merupakan salah satu syarat yang harus dimuat di dalam permintaan paten yang diajukan oleh peminta paten kepada Kantor Paten. Akan tetapi, UU No. 6/1989 baik sebelum maupun setelah diubah dengan UU No. 13 Tahun 1997 beserta penjelasannya dan Peraturan Pemerintah No. 34 Tahun 1991 tentang Pelaksanaan UU No. 6/1989 juga beserta Penjelasannya tidak memberikan pengertian secara jelas mengenai klaim tersebut. Dengan perkataan lain, apakah yang menjadi obyek perlindungan paten menurut UU Paten Indonesia adalah kata-kata dari klaim ataukah intisari dari klaim terbuka untuk dilakukan penafsiran.

Di dalam melakukan penafsiran terhadap klaim yang dimuat di dalam permintaan paten sebaiknya digunakan penafsiran secara. teleologis yaitu penafsiran didasarkan atas kepentingan yang dihadapi saat itu. Kepentingan Indonesia dengan Pengundangan UndangUndang Paten adalah untuk mengembangkan dan menguasai teknologi termasuk juga teknologi orang atau badan hukum asing. Apabila dilindungi adalah intisari klaim, perlindungan itu terlalu luas sehingga tertutup kemungkinan dilakukannya modifikasi. Melindungi inti sari klaim berarti tidak memungkinkan hadirnya suatu penemuan lain yang meskipun bentuk dan wujudnya berbeda dari penemuan yang dipatenkan asalkan fungsinya sama. Sebaliknya, apabila kata-kata klaim yang dilindungi akan mengakibatkan mudahnya dilakukan peniruan. Setelah mempelajari deskripsi yang mengungkapkan penemuan yang dipatenkan, seorang peniru dapat mengubah kata-kata da-

${ }^{16}$ Philippè Nonet dan Philip Selznick menyatakan "We distinguish three modalities or basic "states" of Lawin-society: (1) Law in the servant of repressive power, (2) Law is a differentiated institutions capable of taming repression and protecting its own integrity, and (3) law a facilitator of response to social needs and aspirations". Philippe Nonet dan philip Selznick. 1978. Law in Society in transition. New York: Harper Colophon Book. HIm. 14. Mengenai ciri-ciri "Responsive Law" dapat dilihat pada HIm. 73-113 dalam karya mereka. 
lam klaim dan sekaligus mengadakan perubahan kecil yang tidak signifikan terhadap penemuan yang telah dipatenkan tidak dianggap sebagai pelanggaran paten. Apabila penafsiran demikian yang diikuti perlindungan paten tidak akan mempunyai arti bagi pemegang paten sehingga pemilik penemuan enggan untuk minta perlindungan paten bagi penemuan yang dimilikinya.

Dengan berpegang kepada tujuan Indonesia mengundangkan Undang-Undang Paten, menurut pendapat saya yang dilindungi bukan hanya kata-kata klaim tetapi juga bukan intisari klaim. Akan tetapi yang dijadikan landasan adalah kata-kata klaim sedangkan deskripsi, gambar dan abstraksi merupakan penjelasan dari klaim. Keuntungan dari penafsiran ini adalah peminta paten hendaknya merumuskan secara cermat dan tegas klaim yang dimintakan perlindungan. Di samping itu gambar, deskripsi, maupun abstraksi hendaklah mendukung kata-kata klaim tersebut. Begitu pula mengenai bentuk dan wujud juga menentukan pertindungan. Sedangkan fungsi bukan merupakan objek perlindungan sebab jika fungsi yang dilindungi hal itu akan menutup kemungkinan orang atau badan hukum lain untuk mendapatkan perlindungan paten bagi penemuan dengan fungsi yang sama. Berdasarkan penafsiran tersebut, Pasal 30 ayat (1) dan (2) Undang-Undang Paten Indonesia dapat berfungsi sebagai sarana alih teknologi jika pemilik penemuan yang dimintakan perlindungan paten itu perusahaan transnasional yang ada di Indonesia atau perusahaan maupun orang asing atau badan hukum yang bertempat tinggal di Indonesia. Dalam hal demikian terbukalah Indigenious Technological Capabilities bangsa Indonesia. ${ }^{17}$

\section{Simpulan}

Luasnya perlindungan paten ditentukan oleh penafsiran terhadap perlindungan atas klaim. Dari studi yang telah dilakukan dapat dikemukakan bahwa apabila yang dilindungi inti dari penemuan yang dituangkan di dalam klaim, perlindungan akan menjadi luas dan menghambat terjadinya modifikasi atau pengembangan teknologi oleh fihak lain; sebalik. nya apabila yang dilindungi hanya kata-kata dari klaim akan membuka terjadinya peniruanpeniruan yang mungkin dipatenkan juga dan hal ini merugikan pemegang paten.

Di Belanda paten mendapat perlindungan secara proporsional artinya bahwa yang dilindungi bukan inti dari klaim, melainkan juga perlu diperhatikan rumusan kata-kata klaim. Hal ini menimbulkan keseimbangan perlindungan antara pemegang paten dan masyarakat. Sebaliknya di Jerman, yang dilindungi adalah inti (inhalt) dari klaim. Meskipun pengadilan bebas untuk menafsirkan, perlindungan demikian dapat dikatakan sangat luas. $\mathrm{Di}$ Inggris dianut doktrin purposive contruction yaitu apa sebenarnya yang dimaksud oleh pemohon paten dengan penemuannya itu. Perlindungan demikian itu lebih luas dari sekedar kata-kata klaim, tetapi masih lebih sempit daripada yang dilakukan oleh Jerman.

\footnotetext{
${ }^{17} Y a n g$ dimaksud dengan Indigenous Technological Capabilities adalah: (1) kemampuan untuk menyeleksi teknologi yang ditawarkan; (2) kemampuan untuk menguasai teknologi yang diimpor; (3) kemampuan untuk mengintroduksi hal-hal baru dalam proses menghasilkan produk-produk.
} 
Di Amerika Serikat perlindungan luasnya paten begitu sempit. Pada dasarnya yang dilindungi oleh UU Paten Amerika adalah kata-kata dari klaim. Namun dalam perkembangannya dikembangkan doktrin equivalent yang pada dasarnya mencegah jangan sampai dilakukan peniruan dengan cara modifikasi terhadap penemuan yang dipatenkan tetapi modifikasi itu tidak mempunyai pembeda yang substansial dengan yang telah dipatenkan. Undang-Undang Paten Indonesia tidak menyebutkan luasnya perlindungan paten.

Dalam menentukan luasnya perlindungan paten seyogyanya diserahkan kepada penafsiran hakim. Namun para hakim hendaklah ditingkatkan kemampuannya dalam menangani masalah-masalah Hak-Hak Milik Intelektual. Dengan diserahkannya penafsiran hakim, pandangan mengenai luasnya klaim dapat berkembang seiring dengan kebutuhan.

Di dalam melakukan penafsiran hendaknya diacu azas keseimbangan perlindungan antara pemegang paten dan kebutuhan Indonesia akan pengembangan teknologi. Dalam hal ini perlu diperhatikan situasi ekonomi indonesia.

Meskipun di Indonesia tidak dianut doktrin stare decisis, seyogyanya putusan-putusan pengadilan yang dapat dianggap sebagai landmark decisions digunakan untuk kasus-kasus paten serupa. Hal ini dimaksudkan untuk mendapatkan kepastian hukum di bidang Hak-Hak
Milik Intelektual. Adanya kepastian hukum seperti itu membuat hukum memiliki daya prediktabilitas yang merupakan suatu hal yang penting bagi aktivitas bisnis. Di samping itu juga perlu dijadikan bahan pelajaran putusan-

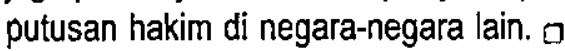

\section{Daftar Pustaka}

Dijk, P. Van, at al. 1985. Van Apeldoorn's Inleiding tot de Studie van het Nederlandse Recht. W.E.J. TjeenWillink. Zwolle.

Doi, Terio. 1980. The Intellectual Property Law of Japan. Sijthoff \& Noordhoff. Alphen aan den Rijn. The Netherlands.

Goldstein, Paul. 1981. Related State Doktrines. Cases and Materials on the Law of Intelectual Property. New York: Mineola.

Nonet, Philippe dan philip Selznick. 1978. Law in Society in transition. New York: Harper Colophon Book.

Pirsen, A.P. 1988. Bescherming Omvang van Octrooien in Nederland, Duitsland, en Engeland. Kluwer. Deventer.

Alpex Computer Corporation v Nintendo Company Ltd. And Nintendo of Americca, Inc. United States Court of Appeals for the federal Circuit. November 6 , 1996.

\section{$\square \square \square$}

